\title{
Evaluation of Variety, Cropping Pattern and Plant Density on Growth and Yield Production of Grain Sorghum -Cowpea under Limited Water Supply Condition Growth, yield and yield component characters of Sorghum
}

\author{
Refay .Y. A., A. A. Alderfasi, M. M. Selim and k. Awad \\ Plant Production Department, College of Food and Agriculture Sciences, King Saud University, P.O. Box 2460, \\ Riyadh 11451, Saudi Arabia.
}

\begin{abstract}
An intercropping experiment of sorghum/cowpea intercrops was carried out in summer season of 2009 and 2010 at Agricultural and Research Station, College of Food Science and Agriculture, King Saud University. The main objective of the study was to evaluate the growth and yield potential of sorghum/cowpea intercrops over sole cropping pattern. The experiments included 18 treatments three sorghum varieties, i.e., two semi dwarfs (Pioneer and S-1007) and a tall one local variety (Shahlaa), theses varieties were planted in two cropping patterns as solid culture at the densities of 200, 300 and $40010^{3}$ plants/hectare for semi dwarfs varieties, whereas tall variety at 160,240 and $32010^{3}$ plants/hectare. These densities for the three varieties are equal to 100, 150 and $200 \%$ of the solid recommended culture. The intercropping was alternating two rows of grain sorghum with other rows of cowpea $(2 \& 2)$ pattern. The data obtained indicated that sorghum plants, when intercropped with cowpea, exhibited greater potentiality and recorded higher values of most of the studied criteria viz., plant height, number of leaves per plant, stem diameter, leaf area, dry matter accumulation and grain yield/plant .Grain yield per hectare was lower in intercropping pattern than solid pattern. The increase in grain yield per plant and plant density could not compensate the decrease of the area occupied by the crop under solid culture.
\end{abstract}

Key words: sorghum, cowpea, intercropping, variety, cropping pattern.

\section{Introduction:}

Intercropping is one of the most important practices, especially under limited cultivated area. One of the greatest attractions of intercropping is that a yield advantage can usually be achieved simply and cheaply by growing crops together rather than separately, particularly when components are cereals and legumes (Singh et al., 2003 and Aliyu and Emechebe, 2006). Intercropping of cereals with legumes is a predominant feature in the cropping systems as a means of maximizing the use of limited farmlands and also for food security to the subsistence farmers (Bhupinder et al., 2003). The relationship between the two crops under intercropping is somewhat complex because the maximum yield to be obtained will depend upon many factors including; species, cropping systems and environmental conditions. Carruthers et al., (2000) reported that legume/ grass intercrop has the most frequency in multiple cropping researches due to their ability for more efficient use of environmental resources. Zand and Ghaffari Khaligh (2002) indicated that intercropping cowpea and grain sorghum in 50/50 (1:1) ratio gave $19 \%$ preference to sole cropping. They investigated the aggressively index for intercrop treatment and stated that cowpea was the dominant species. Homayouni (2004) studied that forage sorghum intercropped with some legumes in different mixing ratios. They reported that intercropping of 2:1 sorghum and legume ratio increased fresh and dry forage yield.

The crops are not necessarily sown at the same time and their harvest time may be quite different, but they are usually simultaneously grown for significant growing periods (Willey, 1990). Moreover, intercropping allows efficient use of both space and time to optimize beneficial effects (Potts, 1990).

Intensive cropping through cereal-legume intercropping was reported by several investigators and practiced by many farmers (Spitters 1983, Crauford, 2000, Singh et al., 2003, Mohamed et al., 2008, Ahmed Nur et al., 2011 and Surve and Arvadia 2011).

Sorghum (Sorghum bicolor L.) is predominantly a crop of drier areas. With the introduction of early maturing and high yielding hybrids the crop has gained importance in the semi-arid regions also (Mohamed et al., 2008). It has great potential of adaptation to drought conditions and also shade-tolerant and therefore used as an intercrop with legumes for higher production and profits per unit area and time (Singh et al., 2003). Spitters (1983) and Odion (1990) reported that the practice of growing sorghum and cowpea on the same piece of land is one of the most important cropping systems in the Nigerian savanna and more than $80 \%$ of all cultivated sorghum and cowpeas are grown in combination with each other. 
Cowpea is one of the most important legume crops. Cowpea grains form an important source of cheap vegetable, containing approximately $25 \%$ protein (Oyenuga, 1959). It is cultivated for both food and fodder (Singh et al., 1997). According to Henriet et al., (1997) and Van EK et al., (1997) the bulk of cowpea production in the Sudan savanna is produced under intercropping with millet and sorghum. Previous studies had shown that improving the productivity of Sorghum /cowpea intercrop lies in improving the performance of the cowpea component which include among others the choice of appropriate genotype (Willey, 1979; Ntare, 1989 and Reddy and Oumara, 1985).

Different planting patterns for cereal-legume intercropping have conflicting experimental results on the potential yield advantage of mixed cropping over sole cropping involving cereal and legume mixtures. Similarly, the yield advantage of intercropping has not been so marked in several situations possibly due to the use of supra-optimal plant population proportions and, in some cases, to the use of sub-optimal population proportions for component crops.

Shivay and Singh, (2000) and Pal and Sheshu (2001) studied the direct and residual contribution of legumes to the yield and nitrogen uptake of maize and found that all the legume crops contributed to the yield and $\mathrm{N}$ uptake of maize either intercropped with the legume or grown after legumes as a sole crop.

The challenge therefore is to identify crops capable of sustaining their potential yield when grown in specific row arrangements with other crops.

Keeping this view in mind, the objective of the present experiment was to evaluate the growth of some sorghum genotypes under different cropping pattern with cowpea under arid environment of Saudi Arabia.

\section{Materials and Methods}

Field experiments were conducted in summer season of 2009 and 2010 at Agricultural and Research Station, College of Food Science and Agriculture, Derab, near Riyadh, King Saud University, Saudi Arabia $\left(24^{\circ} 42 \mathrm{~N}\right.$ latitude and $46^{\circ} 44 \mathrm{E}$ Longitudes, Altitude $\left.600 \mathrm{~m}\right)$. The main objective of the study is to maintain the maximum growth rate and grain yield of sorghum / cowpea intercrops under different densities.

Two semi-dwarf varieties (pioneer and S1007) were planted in solid cultures at the densities of 200, 300 and $40010^{3}$ plants / ha. Whereas the tall variety (shahlaa) was planted in solid culture at densities of 160,240 and $32010^{3}$ plants /ha. . These densities for the three varieties are equal to 100,150 and $200 \%$ of the solid recommended culture which were attained by lifting 2, 3 and 4 plants / hill. Thus each experiment included 18 treatments arranged in a split plot design with four replications as described by Gomez and Gomez, (1984); the main plots were devoted to sorghum varieties, whereas the possible combinations of the cropping patterns and different plant densities were allocated in the sub-plots.

Before sowing, soil sites were prepared as recommended i.e. soil ploughing twice, ridges and divided into plots. Each plot included 6 ridges $60 \mathrm{~cm}$ apart and 5 meter length. The total plot area was $18 \mathrm{~m}^{2}$. Soil samples were taken from 0-30 cm. depth from eight sites for physical and chemical analyses by the methods described by Cottenie et al., (1982) and But (2004). The results are presented in Table1. Chemical properties of the irrigation water were also analyzed according to APHA (1992).The results are presented in Table 2. During seed bed preparation phosphatic fertilizer was applied at the rate of $150 \mathrm{Kg} \mathrm{ha}^{-1}$ as calcium superphosphate (16\% $\left.\mathrm{P}_{2} \mathrm{O}_{5}\right)$; Potassium fertilizer was also applied in the form of potassium sulphate $\left(48 \% \mathrm{~K}_{2} \mathrm{O}\right)$ at $50 \mathrm{~kg} \mathrm{ha}^{-1}$ and Nitrogen fertilizer was top-dressed at the rate of $200 \mathrm{Kg} \mathrm{ha}^{-1}$ in the form of Potassium Nitrate $\left(\mathrm{KNO}_{3}-13 \% \mathrm{~N}\right)$, in three equal doses i.e. at sowing, after 21 days from sowing, and at silk initiation. Flood irrigation system was followed once every week. Weeding was accomplished using hand hoes at 3 and 6 weeks after cereal planting. The conventional agricultural practices for both crops were followed.

Cowpea Seeds were sown on $15^{\text {th }}$ and $18^{\text {th }}$ May in 2009 and 2010 seasons, respectively either in one drill/ridge, $5 \mathrm{~cm}$ spaced and $60 \mathrm{~cm}$ apart (solid I), or in two drills at both sides of the ridge, $5 \mathrm{~cm}$ space and $60 \mathrm{~cm}$ apart (solid II). The intercropped cowpea was applied in the assigned two ridges in 2 drills/ ridge.

Two weeks later sorghum was sown in hills $15 \mathrm{~cm}$ spaced for each of semi-dwarf varieties and $20 \mathrm{~cm}$ for tall variety. At first weeding both sorghum and cowpea were each thinned to 2, 3 and 4 plants/hill to obtain the different plant populations. A boarder of 1 meter space was left between each two experimental plots to avoid shading effects.

At the heading stage, a random sample of 10 plants from each plot was pulled and following characters were studied:

Growth parameters:

A- $\quad$ Plant height. Was measured from ground level to the tip of the top $\mathrm{cm}$.

B- $\quad$ Stem diameter $(\mathrm{cm}$.). Was measured for main stem diameter $10 \mathrm{~cm}$ from ground level using vernier.

C- $\quad$ Number of leaves/plant. The number of leaves was recorded.

D- $\quad$ Leaf area/plant

$\mathrm{LA}=$ maximum length $\mathrm{x}$ maximum width $\mathrm{x} 0.75$ (Adjustment factor). 
E- $\quad$ Fresh weight of leaves, stems + panicles, then sample of each plant organ was taken to dried in an air - draft oven at $70^{\circ}$ and weighed to record :

F- Dry weight of leaves.

G- Dry weight of (stems + panicles).

H- Total dry weight /plant.

At harvest, 20 plants of each plot were taken at random and the heads of each were cut, weighed, air dried, shelled and yield component characters were determined.

Data obtained were subjected to analysis of variance using the methods described by Gomez and Gomez, (1984).and New least significant difference (LSD) was used to differentiate between treatment means.

Table (1): Physical and chemical properties of the experimental soil site during the growing season of 2009 and 2010 season

\begin{tabular}{|c|c|c|c|c|c|c|c|c|c|c|c|}
\hline \multirow[b]{2}{*}{$\begin{array}{l}\text { properties } \\
\text { Soil depth } \\
\text { 0- 30 } \\
\end{array}$} & \multirow{2}{*}{$\begin{array}{c}\mathrm{pH} \\
\text { (soil } \\
\text { paste } \\
1: 5 \text { ) }\end{array}$} & \multirow{2}{*}{$\begin{array}{c}\mathrm{EC} \\
(\mathrm{dS} / \\
\left.\mathrm{m}^{-1}\right)\end{array}$} & \multirow{2}{*}{$\begin{array}{c}\text { O.M } \\
(\%)\end{array}$} & \multirow{2}{*}{$\begin{array}{c}\text { Saturation } \\
\text { percentage } \\
(\%)\end{array}$} & \multirow[b]{2}{*}{$\begin{array}{c}\mathrm{CaC} \\
\mathrm{O}_{3} \\
(\%)\end{array}$} & \multirow{2}{*}{$\begin{array}{l}\text { Field } \\
\text { capaci } \\
\text { ty }(\%)\end{array}$} & \multirow{2}{*}{$\begin{array}{l}\text { Wiltin } \\
\text { g } \\
\text { point } \\
(\%)\end{array}$} & \multicolumn{4}{|c|}{ Mechanical Properties } \\
\hline & & & & & & & & $\begin{array}{c}\text { Sa } \\
\text { nd } \\
(\% \\
)\end{array}$ & $\begin{array}{l}\text { Silt } \\
(\%)\end{array}$ & $\begin{array}{l}\text { Clay } \\
(\%)\end{array}$ & $\begin{array}{c}\text { Text } \\
\text { ure }\end{array}$ \\
\hline 2009 & 7.86 & 3.88 & 0.46 & 29.70 & $\begin{array}{c}29.4 \\
2\end{array}$ & 16.30 & 7.67 & $\begin{array}{l}57 . \\
92\end{array}$ & $\begin{array}{r}27.2 \\
0\end{array}$ & $\begin{array}{c}14.8 \\
8\end{array}$ & $\begin{array}{r}\text { Sand } \\
y \\
\text { loam }\end{array}$ \\
\hline 2010 & 7.81 & 3.91 & 0.47 & 29.45 & $\begin{array}{c}29.6 \\
3 \\
\end{array}$ & 16.42 & 7.71 & $\begin{array}{l}5 \\
7.8 \\
2 \\
\end{array}$ & $\begin{array}{r}27.2 \\
5\end{array}$ & $\begin{array}{l}14.9 \\
0\end{array}$ & $\begin{array}{c}\text { Sand } \\
\mathrm{y} \\
\text { loam }\end{array}$ \\
\hline \multicolumn{12}{|c|}{ Available macro and micro nutrients (ppm) } \\
\hline \multirow[t]{2}{*}{2009} & $\mathrm{~N}$ & & $\mathrm{P}$ & \multicolumn{2}{|c|}{$\mathbf{K}$} & $\mathrm{Fe}$ & \multicolumn{2}{|c|}{$\mathrm{Mn}$} & \multicolumn{2}{|c|}{$\mathrm{Zn}$} & $\mathrm{Cu}$ \\
\hline & 35.40 & \multicolumn{2}{|c|}{14.80} & \multicolumn{2}{|c|}{243.50} & 3.27 & \multicolumn{2}{|c|}{2.44} & \multicolumn{2}{|c|}{6.07} & 0.70 \\
\hline 2010 & 35.80 & \multicolumn{2}{|c|}{12.76} & \multicolumn{2}{|c|}{251.42} & 3.24 & \multicolumn{2}{|c|}{2.61} & \multicolumn{2}{|c|}{6.13} & 0.74 \\
\hline
\end{tabular}

Table (2): Chemical properties of the irrigation water during the growing seasons of 2009 and 2010

\begin{tabular}{|c|c|c|c|c|c|c|c|c|c|c|c|c|c|}
\hline $\begin{array}{l}\text { Chemical } \\
\text { properties }\end{array}$ & $\mathrm{pH}$ & EC & $\begin{array}{c}\text { O.M } \\
\%\end{array}$ & & $\begin{array}{r}\text { Sol } \\
\text { ations }\end{array}$ & $\begin{array}{l}\text { le } \\
\text { neq./ }\end{array}$ & & Solv & $\begin{array}{l}\text { le } \mathrm{Al} \\
\text { leq./ }\end{array}$ & & & $\begin{array}{l}\text { al N } \\
\text { ppm }\end{array}$ & \\
\hline Seasons & & $\begin{array}{l}\left(\mathrm{dS} / \mathrm{m}^{-}\right. \\
\left.{ }^{1}\right)\end{array}$ & & $\begin{array}{l}\mathrm{Ca} \\
+\end{array}$ & $\mathrm{Mg}+$ & $\begin{array}{l}\mathrm{Na} \\
+\end{array}$ & $\mathrm{K}+$ & $\mathrm{HCO}_{3}$ & $\mathrm{Cl}^{-}$ & $\mathrm{SO}_{3}{ }^{-}$ & $\mathrm{N}$ & $\mathrm{P}$ & $\mathrm{K}$ \\
\hline 2009 & 7.10 & 1.45 & 0.02 & $\begin{array}{c}6.3 \\
0\end{array}$ & 1.75 & $\begin{array}{c}7.3 \\
5\end{array}$ & $\begin{array}{c}0.4 \\
4\end{array}$ & 2.40 & $\begin{array}{c}4.8 \\
5\end{array}$ & 9.14 & $\begin{array}{c}10 . \\
5\end{array}$ & $\begin{array}{c}9.2 \\
3\end{array}$ & $\begin{array}{c}17 . \\
0\end{array}$ \\
\hline 2010 & 7.17 & 1.73 & 0.02 & $\begin{array}{c}5.5 \\
0\end{array}$ & 1.87 & $\begin{array}{c}7.6 \\
5\end{array}$ & $\begin{array}{c}0.4 \\
6\end{array}$ & 2.60 & $\begin{array}{c}4.8 \\
0\end{array}$ & 8.56 & $\begin{array}{c}11 . \\
0\end{array}$ & $\begin{array}{c}11 . \\
0\end{array}$ & $\begin{array}{c}17 . \\
1\end{array}$ \\
\hline
\end{tabular}

Effect on some growth parameters:

\section{Results and Discussion:}

Data presented in Table (3) revealed that legumes intercropping have a substantial effect on the growth of sorghum viz., plant height, stem diameter, number of leaves and leaf area. As expected, plants under intercropping pattern seemed to be shorter than those of solid plantings. Such effect may be due to plants under intercropping pattern decreased the competition between sorghum plants for light, water and nutrients. In this respect Ashour et al., (1993) and Aliyu and Emechebe (2006) concluded that any difference in plant height between intercropping and monoculture would indicate a competition for growth factors during the vegetative development of the crop.

Data also indicated that semi-dwarf varieties had thicker stalk than the tall variety. Nearly, the same number of leaves per plant was produce by the three tested varieties. Such criteria may be explain why the plants 
of the semi-dwarf varieties seem to be more compact that of the tall variety, since nearly the same number of leaves is distributed along shorter stalks in semi-dwarf varieties .

Similarly, the same trend was observed in stem diameter, intercropping advantaged stem diameter of sorghum plants. Intercropping grain sorghum with cowpea under different plant densities resulted significant increase in stem diameter. This is in agreement with the data reported by Shivay and Singh (2000) and Aliyu and Emechebe (2006).

It is worthy clear from the data in Table 2 that the leaf area per plant of S1007 variety was significantly greater than that of the other two varieties. Under intercropping pattern the leaf area per plant exceeded that under solid culture. Furthermore, increasing plant density per hill, either under solid or intercropping pattern, decrease leaf area of grain sorghum plant. Also, it is observed that under intercropping conditions, the leaf area per plant in the case of 3 plants /hill was larger than in the solid recommended density (2plants/hill). Leaf area is the primary factor of photosynthetic activity and photosynthates accumulation. Larger leaf area and high chlorophyll content accumulate more photosynthates and produce higher biological yield. Similar results were earlier reported by Ashour et al., (1993).

\section{Effect on dry weight of leaves, stems + panicles and total dry weight per plant:}

From the data in Table 4 it can be noticed that the plants of S1007 cultivar produce heaviest leaves; meanwhile, the tall variety Shahlaa produce the heaviest of both stems+ panicals and the total dry weight. This finding was confirmed that the weight of stems + panicals limits the final product of the dry weight per plant.

Cropping pattern significantly affected the dry weight of different plant parts; leaves and stems + panicals per plant. At each sorghum plant density, the dry matter content per plant was higher under intercropping conditions than that in solid culture. Such increment in dry weight may be due to the increased plant height and number of leaves, this is in consorance with Surve and Arvadia (2001) who reported that intercropping of pulses with sorghum enhances the dry matter accumulation in sorghum.

The obtained data also clearly show that grain sorghum plants, when intercropped with cowpea, could tolerate the increase in the plant density up to $50 \%$ of the solid recommended density (up to 3 plants/ hill).It is meaning that, the competition for light and nutrients among the sorghum plants grown in the same hill is diminished in the intercropping culture as compared with solid culture. Zand and Ghaffari Khaligh (2002) reported that inter- plant competition, when measured as a final dry weight per plant, was obvious in high densities than in low densities with sorghum/cowpea intercrops. The decrease of competition between plants when intercropped was reported by several investigators (Ashour et al., 1993; Henriet et al., 1997; Craufard 2000; Carruthers et al., 2000 and Ahmed Nur et al., 2011).

\section{Effect on grain yield per plant and per hectare:}

Data presented in Table 4 show significant differences in grain yield per plant among tested varieties. In general , the semi - dwarf varieties ( S1007 and Pioneer) surpassed the tall variety (Shahlaa) in grain yield per plant, where the Pioneer variety gave the highest grain yield per plant. Such effect could be associated to the genetic makeup of the varieties.

Intercropping of grain sorghum with cowpea increased sorghum grain yield per plant. However, it is also clear that increasing plant density per hill decrease the grain yield per plant either in solid or in intercropping pattern.

The data obtained of grain yield per plant revealed the beneficial effect of intercropping of grain sorghum with cowpea. The highest increase of grain yield per plant was obtained when Pioneer variety was intercropped at 2 plants per hill with cowpea. Pal and Sheshu (2001) studied the direct and residual contribution of legumes to the yield and nitrogen uptake of maize and found that all the legume crops contributed to the yield and $\mathrm{N}$ uptake of maize either intercropped with the legume or grown after legumes as a sole crop. Similarly, Singh and Balyan (2004) indicated that the intercropping systems registered significant increase in total productivity (sorghum equivalent) over sale sorghum.

With regard the total grain yield per hectare, significant differences among different varieties were recorded. In general, the semi-dwarf varieties (S1007 and Pioneer) yielded more grain yield per hectare than did the tall variety (Shahlaa). Such superiority of the semi-dwarf varieties was expected due to the recommended plant density of these varieties is higher as compared with tall variety. The grain yield of the solid pattern surpassed that of the intercropping pattern, because in the latter case, only $50 \%$ of the area is occupied by sorghum plants and the increase in the grain yield per plant could not compensate the decrease of occupied area which was replaced by cowpea. The present results are in line with those reported by (Ashour et al., 1993; Shivay and Singh, 2000). 
Table (3): Growth criteria of sorghum varieties at heading stage as affected by cropping pattern and hill density (combined data of 2009 and 2010 seasons).

\begin{tabular}{|c|c|c|c|c|c|c|c|c|c|}
\hline \multirow{2}{*}{$\begin{array}{l}\text { Variety } \\
\text { (A) }\end{array}$} & \multirow{2}{*}{$\begin{array}{l}\text { Cropping } \\
\text { patterns(B) } \\
\text { Plant density } \\
\text { hill (C) }\end{array}$} & \multicolumn{2}{|c|}{$\begin{array}{l}\text { Plant height } \\
(\mathrm{cm})\end{array}$} & \multicolumn{2}{|c|}{$\begin{array}{l}\text { Number of } \\
\text { leaves/plant }\end{array}$} & \multicolumn{2}{|c|}{$\begin{array}{l}\text { Stem diameter } \\
(\mathrm{cm})\end{array}$} & \multicolumn{2}{|c|}{$\begin{array}{c}\text { Leaf area } \\
\left(\mathrm{dm}^{2} / \text { plant }\right)\end{array}$} \\
\hline & & Solid & Inter. & Solid & Inter. & Solid & Inter. & Solid & Inter. \\
\hline \multirow[t]{2}{*}{ Pioneer } & $\begin{array}{l}2 \text { plants / hill } \\
3 \text { plants / hill } \\
4 \text { plants / hill }\end{array}$ & $\begin{array}{l}152.2 \\
149.5 \\
152.4\end{array}$ & $\begin{array}{l}145,6 \\
134,7 \\
140.8\end{array}$ & $\begin{array}{l}10.1 \\
9.8 \\
9.8\end{array}$ & $\begin{array}{l}11.7 \\
10.5 \\
8.8\end{array}$ & $\begin{array}{l}2.0 \\
2.0 \\
1.9 \\
\end{array}$ & $\begin{array}{l}3.0 \\
2.7 \\
2.1\end{array}$ & $\begin{array}{l}74.6 \\
67.4 \\
53.8 \\
\end{array}$ & $\begin{array}{l}89.5 \\
83.2 \\
65.9\end{array}$ \\
\hline & Mean & 151.4 & 140.4 & 9.9 & 10.4 & 1.97 & 2.7 & 65.2 & 79.3 \\
\hline \multicolumn{2}{|c|}{ General mean } & \multicolumn{2}{|c|}{145.9} & \multicolumn{2}{|c|}{10.2} & \multicolumn{2}{|c|}{2.4} & \multicolumn{2}{|c|}{72.3} \\
\hline \multirow[t]{2}{*}{$\$ 1007$} & $\begin{array}{l}2 \text { plants / hill } \\
3 \text { plants / hill } \\
4 \text { plants / hill }\end{array}$ & $\begin{array}{l}155.2 \\
146.3 \\
149.6\end{array}$ & $\begin{array}{l}152.2 \\
140.5 \\
145.8\end{array}$ & $\begin{array}{l}11.7 \\
10.6 \\
10.2\end{array}$ & $\begin{array}{l}10.7 \\
12.1 \\
10.5\end{array}$ & $\begin{array}{l}3.0 \\
2.3 \\
2.0\end{array}$ & $\begin{array}{l}3.1 \\
2.6 \\
2.4\end{array}$ & $\begin{array}{l}85.8 \\
77.2 \\
71.3\end{array}$ & $\begin{array}{l}111.4 \\
105.0 \\
80.5\end{array}$ \\
\hline & Mean & 150.3 & 146.1 & 10.8 & 11.1 & 2.43 & 2.67 & 78.1 & 99.0 \\
\hline \multicolumn{2}{|c|}{ General mean } & \multicolumn{2}{|c|}{148.2} & \multicolumn{2}{|c|}{11.0} & \multicolumn{2}{|c|}{2.6} & \multicolumn{2}{|c|}{88.6} \\
\hline \multirow[t]{2}{*}{ Shahlaa } & $\begin{array}{l}2 \text { plants /hill } \\
3 \text { plants / hill } \\
4 \text { plants / hill }\end{array}$ & $\begin{array}{l}293.4 \\
301.5 \\
324.5\end{array}$ & $\begin{array}{l}301.5 \\
312.5 \\
334.1\end{array}$ & $\begin{array}{l}10.5 \\
10.8 \\
9.8\end{array}$ & $\begin{array}{l}11.7 \\
10.5 \\
10.1\end{array}$ & $\begin{array}{l}1.80 \\
1.80 \\
1.40\end{array}$ & $\begin{array}{l}2.40 \\
1.90 \\
1.70\end{array}$ & $\begin{array}{l}77.4 \\
62.9 \\
52.9\end{array}$ & $\begin{array}{l}87.4 \\
73.4 \\
64.5\end{array}$ \\
\hline & Mean & 306.5 & 316.0 & 10.4 & 10.8 & 1.67 & 2.00 & 64.4 & 75.1 \\
\hline \multicolumn{2}{|c|}{ General mean } & \multicolumn{2}{|c|}{311.3} & \multicolumn{2}{|c|}{10.6} & \multicolumn{2}{|c|}{1.8} & \multicolumn{2}{|c|}{69.8} \\
\hline \multicolumn{2}{|c|}{$\begin{array}{c}\text { General mean of cropping } \\
\text { pattern (B) }\end{array}$} & 202.7 & 200.8 & 10.4 & 10.8 & 2.0 & 2.5 & 69.2 & 84.5 \\
\hline $\begin{array}{l}\text { plant } \\
\text { density } \\
\text { (C) }\end{array}$ & $\begin{array}{l}2 \text { plants / hill } \\
3 \text { plants / hill } \\
4 \text { plants / hill }\end{array}$ & $\begin{array}{l}200.3 \\
199.1 \\
208.8\end{array}$ & $\begin{array}{l}199.8 \\
195.9 \\
206.9\end{array}$ & $\begin{array}{l}10.8 \\
10.4 \\
9.9\end{array}$ & $\begin{array}{l}11.4 \\
11.0 \\
9.8\end{array}$ & $\begin{array}{l}2.3 \\
2.0 \\
1.8\end{array}$ & $\begin{array}{l}2.8 \\
2.4 \\
2.1\end{array}$ & $\begin{array}{l}79.3 \\
69.2 \\
59.3\end{array}$ & $\begin{array}{l}96.1 \\
84.2 \\
70.3\end{array}$ \\
\hline LSD for & $\begin{array}{l}\text { Variety (A) } \\
\text { Crop Pattern (B) } \\
\text { Plant density (C) } \\
\text { A XB } \\
\text { A X C } \\
\text { B X C } \\
\text { A X B X C }\end{array}$ & \multicolumn{2}{|c|}{$\begin{array}{l}1.7 \\
\text { N.S } \\
\text { N.S } \\
\text { N.S } \\
21.5 \\
17.6 \\
30.4\end{array}$} & \multicolumn{2}{|c|}{$\begin{array}{l}\text { N.S } \\
0.38 \\
0.46 \\
\text { N.S } \\
\text { N.S } \\
\text { N.S } \\
1.13\end{array}$} & \multicolumn{2}{|c|}{$\begin{array}{l}0.13 \\
0.10 \\
0.12 \\
\text { N.S } \\
\text { N.S } \\
\text { N.S } \\
\text { N.S }\end{array}$} & \multicolumn{2}{|c|}{$\begin{array}{r}3.4 \\
2.2 \\
2.7 \\
3.9 \\
\text { N.S } \\
\text { N.S } \\
6.7\end{array}$} \\
\hline
\end{tabular}

Table (4) : Dry matter and grain yield of sorghum varieties at heading stage as affected by cropping pattern and hill density (combined data of 2009 and 2010 seasons).

\begin{tabular}{|c|c|c|c|c|c|c|c|c|c|c|c|}
\hline \multirow{3}{*}{$\begin{array}{l}\text { Variety } \\
\text { (A) }\end{array}$} & \multirow{3}{*}{$\begin{array}{l}\text { Cropping } \\
\text { patterns(B) } \\
\text { Plant densityx } \\
\text { hill (C) }\end{array}$} & \multicolumn{6}{|c|}{ Dry matter accumulation ( $\mathrm{g} /$ plant) } & \multirow{2}{*}{\multicolumn{2}{|c|}{$\begin{array}{l}\text { Grain yield } \\
\text { (g/plant) }\end{array}$}} & \multirow{2}{*}{\multicolumn{2}{|c|}{$\begin{array}{c}\text { Grain yield } \\
\text { (ton/ha.) }\end{array}$}} \\
\hline & & \multicolumn{2}{|c|}{ Leaves } & \multicolumn{2}{|c|}{ stems + panicles } & \multicolumn{2}{|c|}{ Total plant } & & & & \\
\hline & & Solid & Inter. & Solid & Inter. & Solid & Inter. & Solid & Inter. & Solid & Inter. \\
\hline Pioneer & 2 plants /hill & 49.0 & 55.3 & 154.7 & 164.6 & 204.0 & 220.0 & 47.1 & 61.7 & 4.821 & 3.674 \\
\hline & 3plants / hill & 43.1 & 42.6 & 139.5 & 148.1 & 182.6 & 190.7 & 37.9 & 45.8 & 5.155 & 4.2 .60 \\
\hline & 4 plants / hill & 33.6 & 39.1 & 118.3 & 104.2 & 151.7 & 143.3 & 25.7 & 39.0 & 4.821 & 4.274 \\
\hline & Mean & 42.0 & 45.7 & 137.5 & 139.0 & 179.4 & 184.7 & 39.9 & 48.8 & 4.931 & 4.069 \\
\hline \multicolumn{2}{|c|}{ General mean } & \multicolumn{2}{|c|}{42.0 .9} & \multicolumn{2}{|c|}{138.5} & \multicolumn{2}{|c|}{182.1} & \multicolumn{2}{|c|}{42.9} & \multicolumn{2}{|c|}{4.500} \\
\hline \multirow[t]{4}{*}{ S1007 } & 2 plants /hill & 54.8 & 53.6 & 137.3 & 181.0 & 192.1 & 234.6 & 46.5 & 52.0 & 4.760 & 3.095 \\
\hline & 3plants / hill & 42.6 & 50.7 & 106.8 & 139.6 & 147.0 & 190.3 & 40.0 & 40.8 & 5.424 & 3.786 \\
\hline & 4 plants / hill & 39.5 & 46.1 & 88.3 & 117.7 & 126.8 & 163.8 & 26.2 & 30.2 & 4.371 & 3.305 \\
\hline & Mean & 45.6 & 5.01 & 110.8 & 46.1 & 154.5 & 196.2 & 37.6 & 41.0 & 4.852 & 3.395 \\
\hline \multicolumn{2}{|c|}{ General mean } & \multicolumn{2}{|c|}{47.9} & \multicolumn{2}{|c|}{128.5} & \multicolumn{2}{|c|}{175.4} & \multicolumn{2}{|c|}{39.3} & \multicolumn{2}{|c|}{4.124} \\
\hline \multirow[t]{4}{*}{ Shahlaa } & 2 plants / hill & 46.0 & 49.1 & 196.1 & 208.8 & 242.1 & 258.0 & 42.3 & 45.9 & 4.326 & 2.733 \\
\hline & 3plants / hill & 41.2 & 48.0 & 168.3 & 188.1 & 209.3 & 236.8 & 30.1 & 36.5 & 4.083 & 3.390 \\
\hline & 4 plants / hill & 33.3 & 41.0 & 127.2 & 144.1 & 160.6 & 185.2 & 16.7 & 25.4 & 3.021 & 2.783 \\
\hline & Mean & 40.2 & 46.0 & 163.9 & & 204.0 & 226.7 & 29.7 & 35.9 & 3.810 & 2.969 \\
\hline \multicolumn{2}{|c|}{ General mean } & \multicolumn{2}{|c|}{43.1} & \multicolumn{2}{|c|}{172.2} & \multicolumn{2}{|c|}{215.4} & \multicolumn{2}{|c|}{32.8} & \multicolumn{2}{|c|}{3.390} \\
\hline \multicolumn{2}{|c|}{$\begin{array}{c}\text { General mean of cropping } \\
\text { pattern (B) }\end{array}$} & 42.5 & 47.3 & 137.4 & 155.1 & 179.3 & 197.1 & 34.7 & 41.9 & 4.531 & 3.479 \\
\hline plant & 2 plants / hill & 50.0 & 52.7 & 162.7 & 184.8 & 211.9 & 237.5 & 45.3 & 53.2 & 4.636 & 3.167 \\
\hline density & 3 plants / hill & 42.3 & 47.1 & 138.2 & 158.6 & 179.6 & 205.9 & 36.0 & 41.0 & 4.888 & 3.810 \\
\hline (C) & 4 plants / hill & 35.3 & 42.1 & 111.3 & 122.0 & 146.4 & 164.1 & 22.9 & 31.5 & 4.071 & 3.452 \\
\hline LSD & Variety (A) & & & & & & & & 40 & & 79 \\
\hline for & Crop Pattern (B) & & & & & & & & 20 & & 03 \\
\hline & Plant density (C) & & & & & & & & 40 & & 90 \\
\hline & A XB & & & & & & & & 00 & & 93 \\
\hline & $\mathrm{A} \times \mathrm{C}$ & & & & & & & & $\mathrm{S}$ & & 26 \\
\hline & $\mathrm{B} \times \mathrm{C}$ & & & & & & & & $\mathrm{S}$ & & 02 \\
\hline & $\mathrm{A} \times \mathrm{B} \times \mathrm{C}$ & & & & & & & & $\mathrm{S}$ & & 78 \\
\hline
\end{tabular}




\section{References:}

[1] Ahmed Nur, O; R. Anders; C. L. Jørgen and J. Bayala. (2011): Performance of cowpea (Vigna unguiculata) and pearl millet (Pennisetum glaucum) intercropped under Parkia biglobosa in an agroforestry system in Burkina Faso. African Journal of Agricultural Research Vol. 6(4), pp. 882-891.

[2] Aliyu, B.S. and A.M. Emechebe. (2006): Effect of Intra- and inter-row mixing of sorghum with two varieties of cowpea on host crop yield in a Striga hermonthica infested field. African Journal of Agricultural Research Vol. 1 (2), pp. 024-026, September 2006. Available online at http://www.academicjournals.org/AJAR.

[3] American Public Health Association (1992): Standard Methods for Examination of Water and wastewater, 18th ed., AWWA, WPCF, NY, Washington.

[4] Ashour, N. I; Selim, M. M; Abd El-Lateef, E.M and T. G. Behairy. (1993): Effect of variety, cropping pattern and plant density on growth and yield of grain sorghum/cowpea intercrops .I. Grain Sorghum, Bull.NRC, Egypt, Vol. 18, No.4, pp 305-315.

[5] Bhupinder, S; Kalidindi, U; Singh, B and K, Usha. (2003): Nodulation and symbiotic nitrogen fixation of cowpea genotypes as affected by fertilizer nitrogen. J Plant Nutr 26 (2): 463-473.

[6] But, R. (2004): Soil Survey Laboratory Manual Report No.42 USDA, National Resources Conservation Service. Washington. No.4Version 4.0-700.

[7] Cottenie, A. M; Verlo, L.; Kjekens, M and R. Camerlynch. (1982): Chemical Analysis of Plant and Soil. Laboratory of Analytical Agro chemistry. State Univ. Gent, Belgium. 42: 80-284.

[8] Craufard, P. Q. (2000): Effect of plant density on the yield of sorghum-cowpea and Pearl millet-Cowpea intercrops in northern Nigeria. Expt. Agric. 36: 379-395.

[9] Carruthers, K.; B. Prithiviraj ; Q. Fe, D. Cloutier; R. C. Martin and D.L. Smith. (2000): Intercropping corn with soybean, Iupine and forage yield component responses. Eur.J.Agron. 12:103-115.

[10] Gomez, K.A. and A. Gomez. (1984): Statistical Procedure for Agricultural

[11] Hand book John Wiley \& Sons, New York

[12] Henriet J.; G.A. van Ek; S.F. Blade and B.B. Singh. (1997): Quantitative assessment of traditional cropping systems in the Sudan Savannah of northern Nigeria. Rapid survey of prevalent cropping systems. Samaru Journal of Agricultural Research. 14: pp.37 - 45.

[13] Homayouni, H. (2004): Evaluation of forage production in sorghum/ Legume in different mixing rates. MSc. Thesis, University of Tehran, Tehran, Iran.

[14] Mohammed, I. B; O. O. Olufajo ; B. B. Singh ; S. Miko and S. G. Mohammed. (2008) : Evaluation of Yield of Components of Sorghum /cowpea Intercrops in the Sudan Savanna Ecological Zone. Journal of Agricultural and Biological Science VOL. 3, No. (3), MAY. pp. $30-37$

[15] Ntare B.R; P.G. Serafini and L.K. Fussell. (1989): Recent developments in pearl millet/cowpea cropping systems for low-rainfall areas of the Sudano - Sahelian zone of West Africa. pp 277-289. In Soil, crop and water management systems for rainfed Agriculture in the Sudano- Sahelian zone: Proceedings of an International Workshop 11-16th January 1987. ICRISAT Sahelian Center, Niamey, Niger.

[16] Odion, E.C. (1990): Effect of genotype interaction, sowing date and stand density, proportion and arrangement on mixture of millet and sorghum with groundnut. Ph.D. Thesis. pp. 220.

[17] Oyenuga, V. A. (1959): Nigerian Feeding staffs: Their composition and nutritional value 2nd Edition. University Press. pp120.

[18] Pal, U. R and Y. Sheshu. (2001): Direct and residual contribution of symbiotic nitrogen fixation by legumes to the yield and nitrogen uptake of maize (Zea mays L) In the Nigerian Savannah JAgron and Crop Sci. 187 (1)53-58.

[19] Potts, M.J. (1990): Influence of intercropping in warm climates on pests and diseases of potato with special reference to the control. Field Crops Res 25: pp.133-144.

[20] Reddy K.C. and A. Oumara. (1985): le niebe dans le systemes des cultures au Niger. Legume Workshop, 19-22 November 1985, Universiy of Niamey. Niamey, Niger. Cited by Davis et al., (1994) Journal of Plant Nutrition. 17(6): 899-910.

[21] Shivay. Y.S and R.P. Singh. (2000): Growth, yield attributes, yield and nitrogen uptake of maize (Zea mays L) as influenced by cropping system and nitrogen levels Annals of Agri Res 21(4) 494-498.

[22] Singh, B.B; Ajeigbe, H.A; Tarawali, S.A; Fernandez-Rivera, S; A. Musa. (2003: Improving the production and utilization of cowpea as food and fodder. Field Crop Res., 84: pp.169-177.

[23] Singh B.B. (1997): Multilocation testing of improved cowpea varieties under intercropping. pp. 28-30. IITA Annual Report (1997). Project 11 - Cowpea -Cereals Systems Improvement in the Savanna.

[24] Singh B.B. and B.R. Ntare. (1985): Development of improved cowpea varieties in Africa. In. S.R. Singh and K.O. Rachie (eds). Cowpea Research, Production and Utilization. John Willey and Sons. pp $105-115$.

[25] Singh, B.B and H. Balyan. (2004): Effect of intercropping systems in total productivity (sorghum equivalent) over sale sorghum. Pak J Agri. Sci., Vol 41(3-4), pp 53-58.

[26] Spitters, C.J.T. (1983): An alternative approach to the analysis of mixed cropping experiments. 1. Estimation of competition effects. Netherlands Journal of Agricultural Science, 31, 1-11.

[27] Surve, V.H. and M.K. Arvadia .(2001): Performance of fodder Sorghum (SORGHUM BICOLOR L.), Maize (ZEA MAYS L.) and Cowpea (VIGNA UNGUICULATA (L.) WALP.) Under sole and intercropping systems. International Journal of Agriculture: Research and Review. Vol., 2 (1), 28-31, Available online at http://www.ecisi.com

[28] Van Ek G.A; S.F. Henriet and B.B. Singh. (1997): Quantitative assessment of traditional cropping systems in the Sudan savanna of northern Nigeria. II. Management and productivity of the major cropping systems. Samaru Journal of Agricultural Research. 14: pp.47-60.

[29] Willey, R.W. (1990): Resource uses in intercropping systems. Agric Water Manage 17: 215-231. Available online at http://www.academicjournals.org/AJAR

[30] Willey R.W. 1979. Intercropping-its importance and Research needs. Part-2. Agronomy and Research approaches. Field Crops Abstract. 32: pp. 73-85.

[31] Zand, B. and H. Ghaffari Khaligh,(2002): Evaluation of cowpea/ grain sorghum intercropping system under different sowing patterns. $7^{\text {th }}$ Agronomy and Plant Breeding National Congress, Karaj, Iran. 